\title{
Evaluating an optimum slit check dam design by using a 2D unsteady numerical model
}

\author{
Su-Chin Chen $^{1}$ and Samkele Tfwala ${ }^{1, *}$ \\ ${ }^{1}$ Department of Soil and Water Conservation, National Chung Hsing University, 145 Xingda Road, 402, \\ Taichung, Taiwan
}

\begin{abstract}
Debris flow could be catastrophic to residents and property located at their downstream. As a result, engineers have designed several structural countermeasures, such as check dams. Regardless of the many investigations on check dams, uncertainty with respect to their design is still persistent. Against this backdrop, the study aims to assess the efficiency and determine an optimal design of slit check dams for mitigating debris flow and sediment-laden flows in steep channels. The study uses an actual slit check dam located at Landao creek, a tributary to the Beng-gai River in the central range of Taiwan. The creek has an average slope of 7 degrees, while its $d_{50}$ is approximately $100 \mathrm{~mm}$. Steep slopes, extreme precipitation, poor geologic formations, debris flow and landslides characterise the catchment. Concerning the slit check dam design; there were six rectangular concrete piers (width $=1.5 \mathrm{~m}$, length $=4 \mathrm{~m}$, depth $=8 \mathrm{~m}$ ), linearly spaced at $1 \mathrm{~m}$ in a $180^{\circ}$ alignment layout, with the middle 2 piers height reduced by $2.5 \mathrm{~m}$. We evaluated the performance of this configuration and further tested two additional configurations by cutting a single pier and three piers at the centre in a 2D model, Nays-2DH. Hydrograph of a selected storm was used for upstream boundary conditions. Surveys using an unmanned aerial vehicle were conducted pre- and post-storm events to validate numerical solutions. Scour and deposition profiles from the different pier configurations formed the basis of our assessment. The numerical computations yielded valuable results and may provide better understanding in the optimal design of slit check dams. Our findings are of paramount importance to engineers and decision makers with regard to debris flow mitigation, especially in a typhoon prone region like Taiwan.
\end{abstract}

\section{Introduction}

Taiwan, characterised by large discharge per unit area, steep slopes and fragile watersheds, is often confronted by on average 3-4 typhoon events per annum. In turn, transport of large sediment amount induces sediment related disasters in her rivers, aggravated by the subsequent landslides and debris flow. To curtail the resulting detrimental effects, check dams have been widely used due to their simplicity and effortless implementation [1]. Other benefits of check dams include, stabilizing river channels, regulating sediment transport, preventing stream bank erosion, lowering channel slopes, etc. [2]. In their study on the effects

\footnotetext{
* Corresponding author: samkelet@,gmail.com
} 
of check dams on bedload transport, Piton and Recking [2] further observed that over prolonged time, the same volume of sediments is transported in the presence and absence of check dams. Check dams were found to reduce sediment volumes transported in single events; hence, reducing their impacts.

Two broad forms of check dams are often recognized; closed and open [3]. Moreover, Chen and An [4] identified 3 types in Taiwan, adding the porous type to the aforementioned. Open type check dams are the most preferred in Taiwan due the prevalence of extreme rainfall events and debris flow [5]. They trap large particles, such as cobbles and boulders, while letting finer particles and water to pass (Fig. 1b). Drawbacks of closed check dams have been deliberated by [6], [3] etc. Henceforth, they are rarely applied in Taiwan due to the high volumes of sediment transport. On the contrary, open check dams have added advantages. They are not rapidly filled up and can trap large woody debris. Henceforth, this study emphasised an open check dam.

To highlight their significance, this paper evaluates an already installed slit check dam (Fig. 1). To what extent has it influenced channel dynamics has not been evaluated yet in the field, despite successful laboratory experiments. An attempt is made to assess the check dam qualitatively, and to estimate its optimum design in the field through digital elevation models, DEMs and a 2-dimensional model. We focus particularly on areas at close proximity to the installed check dam, both upstream and downstream.
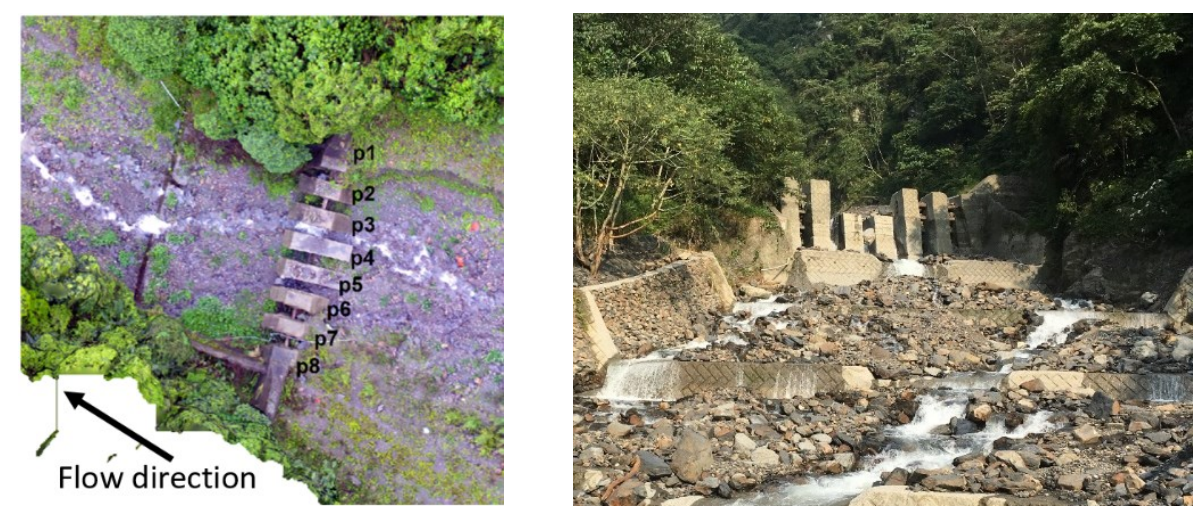

Fig. 1. Installed check dam at Landao creek a) top view b) downstream view.p1 to p8 denotes piers for reference in sections that follow.

\section{Materials and methods}

\section{Study area}

Landao creek is located in the central area of Taiwan (Fig. 3) under the influence of a combination of tropical and sub-tropical climate. Annual precipitation undergoes a monsoon spell from May to June and a typhoon spell from July to October, with regularly low base flows in other months. The mean annual precipitation ranges from 2000 to $2500 \mathrm{~mm}$. The catchment has an area and average slope of 170.5 ha and $44^{\circ}$, respectively. Extreme storm events, known as typhoons in the local region, are a norm, especially during the summer period (June to September). They contribute $90 \%$ of the annual precipitation, inducing a series of natural disasters in the form of landslides and debris flow. In recent years, the disasters have been intensified as the frequency of typhoons increased, which climate change is attributed the cause [7]. 


\section{Methodology}

Field data were collected between April and June 2017, marking a pre- and post-storm event assessment. A storm that resulted in $482.5 \mathrm{~mm}$ and $158.5 \mathrm{~mm}$ occurred on 03 and 04 June, respectively. Fig. 2 shows these storms along with daily rainfall distribution for the year 2017 . Consequently, several morphological changes were witnessed along this creek. Unmanned aerial vehicle (UAV) was adopted at a selected reach of Landao, where the comb check dam was installed to generate digital elevation models at a resolution of $5 \mathrm{~cm}$. Additional collected data included rainfall and grain size analysis of landslides and debris flow deposits in the study site for setting boundary conditions. First survey campaign was conducted 24 April and the second survey, 08 June 2017. Generated DEM's were adopted for geomorphic changes (construction of the DEM of difference model, DoDs) and to validate the developed numerical model. A major factor in adopting UAV was accessibility challenge to the area due to frequent land sliding. This means that only DoD's could be used for validation purposes.

Concerning the slit check dam design; there were originally six rectangular concrete piers, (width $=1.5 \mathrm{~m}$, length $=4 \mathrm{~m}$, depth $=8 \mathrm{~m})$, linearly spaced $(1 \mathrm{~m})$ in a $180^{\circ}$ alignment layout. However, this configuration resulted in the check dam being quickly filled up by boulders. Henceforth, the middle 2 piers, denoted as $\mathrm{p} 4 \mathrm{p} 5$ in this study were cut by $2.5 \mathrm{~m}$ as seen in Fig. 1. The study is aimed at evaluating this configuration following a big storm. To allow for comparison, we numerically simulated this setup using a 2-dimensional model discussed in following sections. Additional setup included cutting (by $2.5 \mathrm{~m}$ ) a single pier at the centre, marked as $\mathrm{p} 4$ and 3 piers, marked as p4p5p6 as shown in Fig. 1a. Scour, and deposition along 3 profiles (expressed as $\mathrm{r} 1, \mathrm{r} 2$, and $\mathrm{r} 3$ ) at the check dam proximity was used for comparison.

\section{daily rainfall}

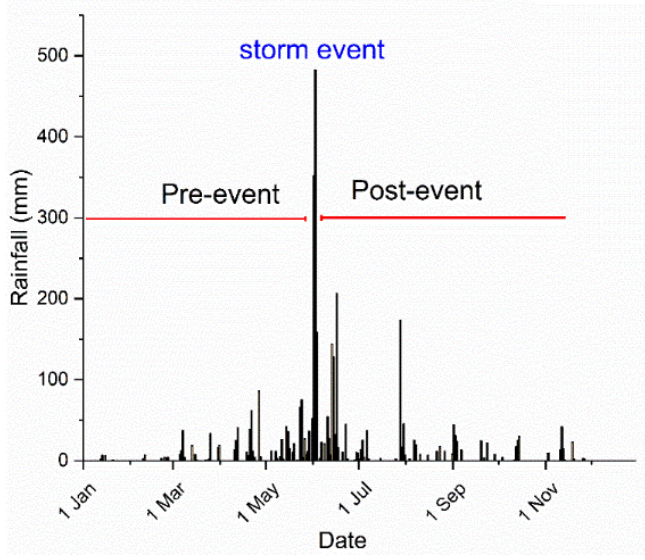

Fig. 2. Rainfall distribution in year 2017 


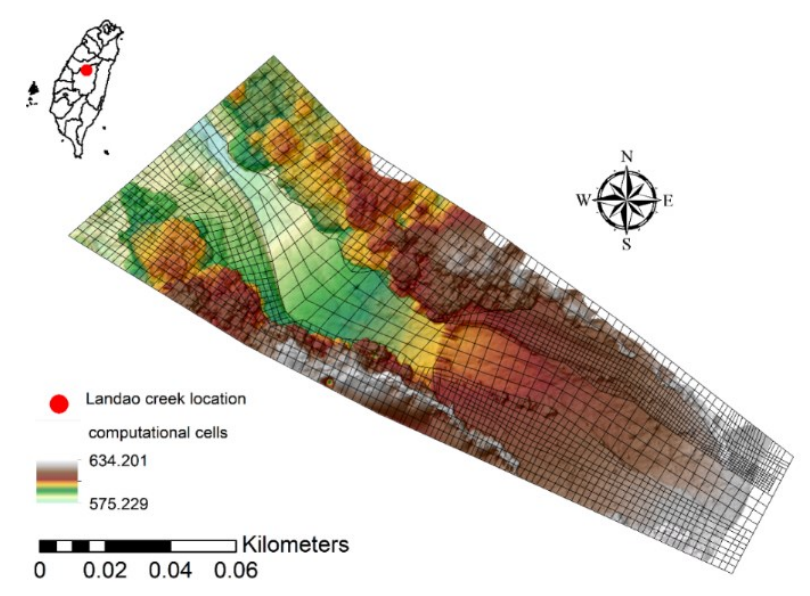

Fig. 3. Location of the study area and computational cells

\section{Numerical models}

A two dimensional numerical model, Nays-2DH, belonging to International River Interface Cooperative (iRIC) was used to evaluate the optimum slit check dam design installed at Landao creek. The model is capable of solving complex unsteady flows and bed variation including bank erosion, river confluences, rigid-bed, a mixture of sediment, and suspended load transport [8]. It comprises the zero-equation, constant eddy viscosity, and the $k-\varepsilon$ model. In this study, the $k-\varepsilon$ model was adopted following the works of $\mathrm{Wu}$, et al. [9] who compared 5 depth-averaged 2-D turbulence models for river flows.

Due to inaccessibility of the area, lack of validation and crucial data, such as discharge were not available. Hence, the study emphasised qualitative assessment to quantitative. Sediment inlet and discharge boundary conditions were computed from a 1-dimensional numerical model, the Physiographic Soil Erosion Deposition (PSED). It has well been validated in several studies such as Lin, et al. [10], Chen, et al. [11], Wu, et al. [12] etc. It divides the watershed into several computational cells using ArcGIS (shown in Fig. 3) based on topography, which is further classified as land or river cells. DEM from the UAV captured images was utilised for this process. In addition, hydrological data, land use and soil data (grain size) served as input to the model. Computations in the model are divided into two main parts; a rainfall-runoff subroutine describes water movement, while a soil erosion-deposition subroutine simulates the sediment transport process.

\section{Results and discussion}

\section{Model validation}

Generated DoD simulated elevation changes were used to validate the developed 2D-model. Nays-2DH captured well the deposition upstream of the check dam and scour at the downstream end (Fig. 4). Spatial distribution indicates deposition upstream and scouring at the immediate downstream due to the energy dissipated by tumbling flow, an already widely explored field [13-15]. 

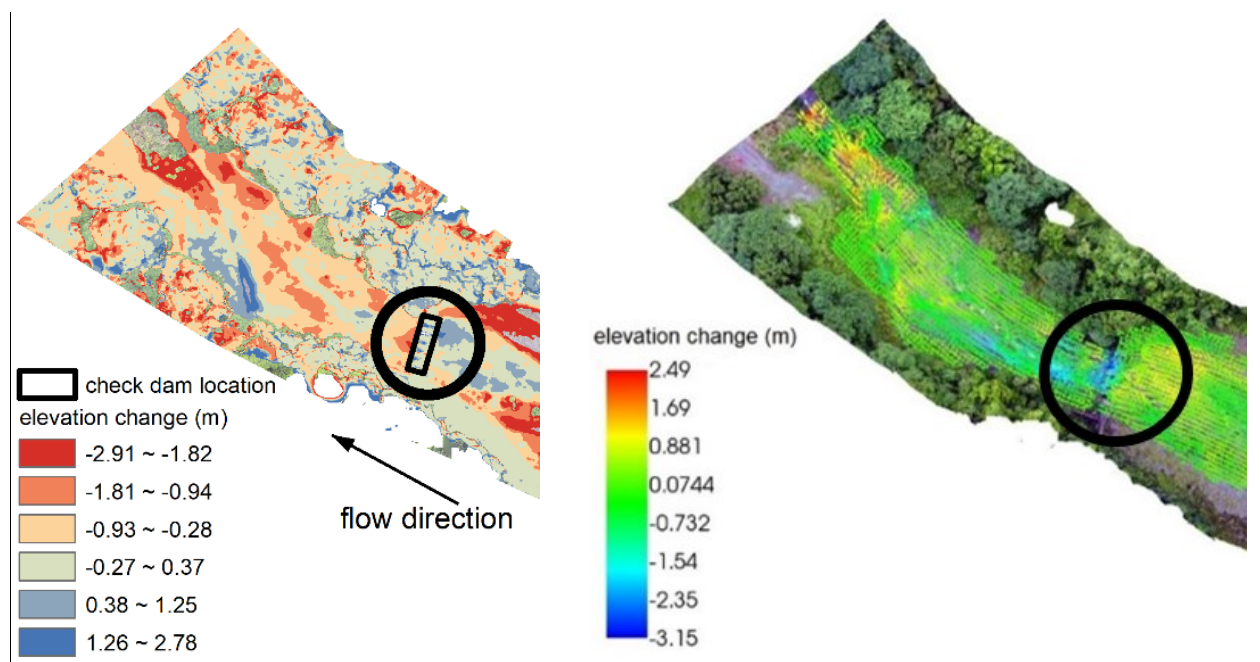

Fig. 4. Nays-2DH model validation using a DEM of difference

In addition to visual assessments, scour, and deposition differences were compared along three profiles (Fig. 5). Profiles are as illustrated in Fig. 5a. Along profiles, r1 and r2, the channel bed is elevated along a $14 \mathrm{~m}$ stretch to check dam, similar to Liu [16] who observed that installation of check dams produced depositional surfaces behind check dams, flatter and wider upstream channels (comparable to Fig. 5a). On the contrary, scour is observed along profile $\mathrm{r} 3$ at the upstream of the check dam. Nays-2DH indicates a decrease in bed elevation from $12 \mathrm{~m}$ towards the check dam (in $\mathrm{r} 3$ ), which is qualitatively similar to observed elevation changes (Fig. 5d). Below the check dam, all profiles indicates high scour depths, for both observed and simulated. Considering the increased flow depth behind piers (Fig. 9), and the elevated flow depth, which created more turbulence at this area, we rate the simulated result adequate in evaluating the overall performance of the different configurations.

\section{Longitudinal profile changes}

After successful model validation, elevation changes along profiles outlined in Fig. 5 were computed for the different slit configurations, and results are shown in Fig. 6 to Fig. 8. In profile $\mathrm{r} 1, \mathrm{p} 4 \mathrm{p} 5$ and $\mathrm{p} 4 \mathrm{p} 5 \mathrm{p} 6$ had similar trends showing deposition of sediments at around 4-10 m towards the dam, while $\mathrm{p} 4$ indicated erosion in the same region. Along the second profile, r2, all three modelled scenarios showed similar trends $10 \mathrm{~m}$ upstream, while bed elevation increased for all profiles within $4 \mathrm{~m}$ to the check dam. The configuration $\mathrm{p} 4$ demonstrated a more significant change. Below the check dam, profiles are similar.

Rivers in Taiwan are dominated by large woody debris; hence, the observations made in Fig. 6 to Fig. 8 may be inapplicable in their presence. Self-cleaning behaviour of slit check dams has been found adequate in several field studies; moreover, it no longer holds when the slits are clogged with abundant wood. Large sediment deposits behind the check dam will subsequently result. 
a)

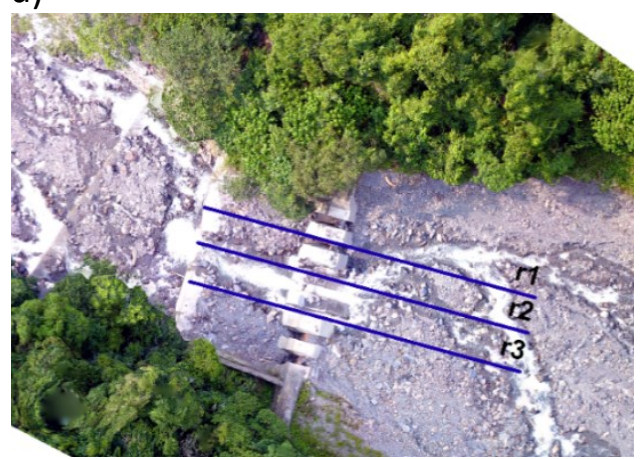

c)

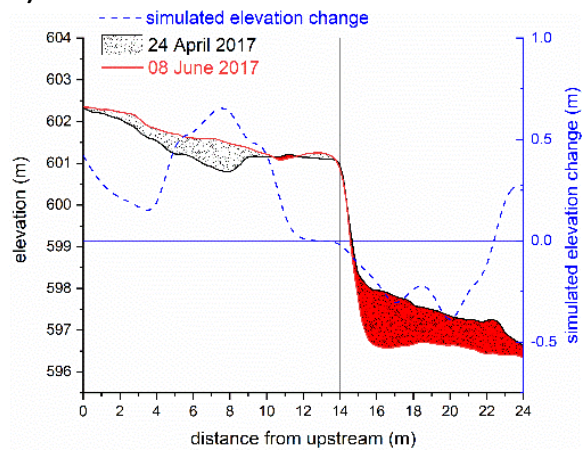

b)

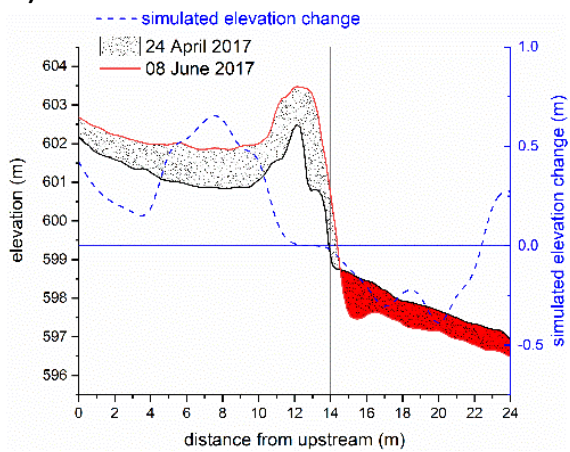

d)

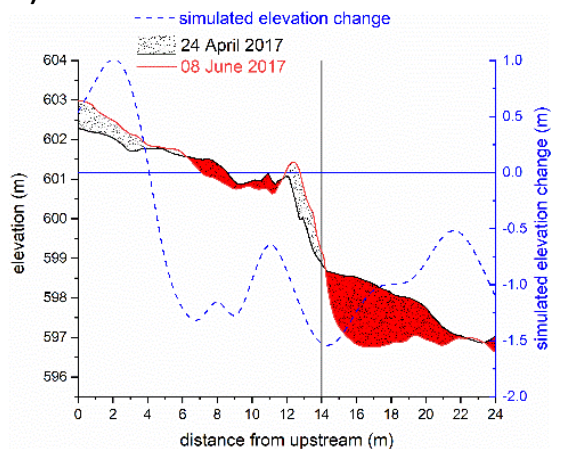

Fig. 5. Scour and deposition, along selected profiles a) longitudinal profiles, b) r1, c) r2, c) r3. Vertical reference lines indicate check dam location, while horizontal reference lines represent a zero elevation change from the numerical model.

Understanding the variability of debris flow in a specific river is therefore crucial in dictating the optimum number of piers to cut in the studied design. Fig. 7 shows an elevated channel bed just behind the check dam (within $3 \mathrm{~m}$ ) suggesting it may be filled up quickly when only a single pier is cut. On the contrary, $\mathrm{p} 4 \mathrm{p} 5$ and $\mathrm{p} 4 \mathrm{p} 5 \mathrm{p} 6$ indicate a further decrease in channel bed elevation. In the downstream, there is an increasing trend, while $\mathrm{p} 4$ only shows a potential further scouring of the bed. This suggests that in $\mathrm{p} 4 \mathrm{p} 5$ and $\mathrm{p} 4 \mathrm{p} 5 \mathrm{p} 6$ configurations, sediment transfer to downstream areas is enhanced. Generally, in Fig. 8, profiles are the same; moreover, $\mathrm{p} 4 \mathrm{p} 5$ configuration shows less scouring of the bed, followed by the $\mathrm{p} 4 \mathrm{p} 5 \mathrm{p} 6$ outline.

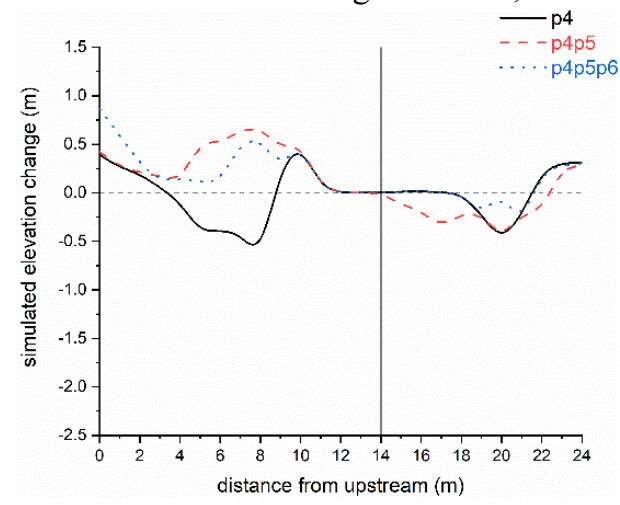

Fig. 6. Longitudinal channel bed changes at profile r1. Vertical reference line is check dam location. 


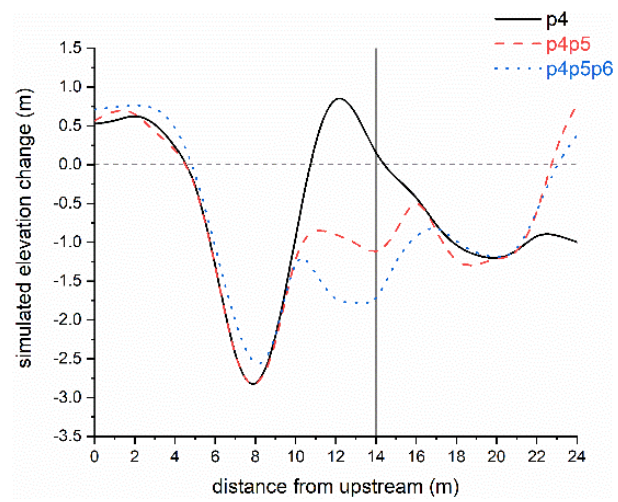

Fig. 7. Longitudinal channel bed changes at profile $\mathrm{r} 2$. Vertical reference line is check dam location

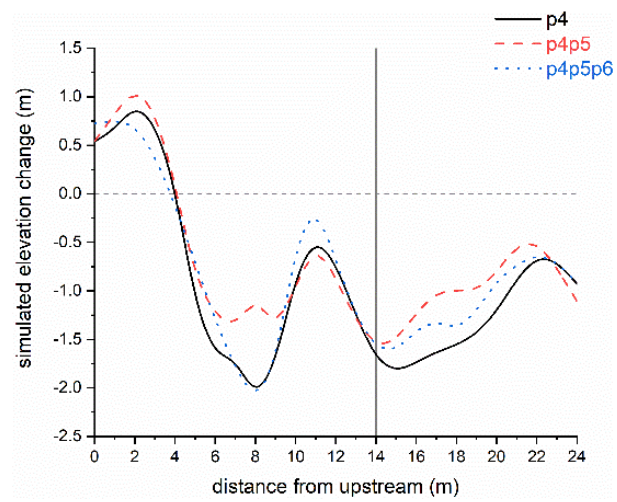

Fig. 8. Longitudinal channel bed changes at profile r3. Vertical reference line is the check dam location

The high erosion depths in profile $\mathrm{r} 2$ (located mostly in the thalweg) may also be attributed to the lowering of the channel bed thalweg, which afterwards led to scouring of the bed in the upstream section. Continuous scouring may eventually lead to systematic deposition below the check dam, contributing to sediment balance in the long term. Based on the above channel-bed elevation changes, one can understand the optimal configurations of the check dam piers.

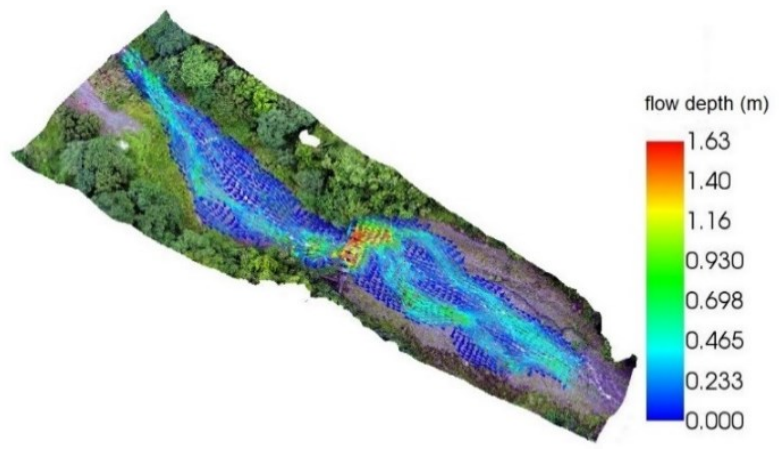

Fig. 9. Flow depth variation after 300 seconds of simulation in Nays-2DH.

\section{Conclusions}

In this study, an attempt is made to evaluate the performance of a slit check dam installed at a creek in Taiwan. The check dam central piers were cut to have three different configurations, namely single pier, 2 piers and finally 3 piers cut by $2.5 \mathrm{~m}$. The resultant morphological changes were observed. Prior to these assessments, Nays-2DH was successfully validated by DoDs generated from UAV generated DEMs, after which the model was applied to the different cases. Cutting two piers is observed to be the best in terms of creating an equilibrium at close proximity especially along the banks. Along the centre of the channel, a single pier setup indicates more deposits behind the dam and prolonged scouring downstream, while cutting two or three piers is shows a decreasing bed elevation towards the check dam, while an increase is observed at the downstream with moving away from the check dam. The choice between cutting two or three piers may be further suggested by the type of large woody debris in the area. Hence, introducing wood in future assessments could bring further enlightenment 
in this regard. Our study has demonstrated how numerical models can contribute to a better evaluation of slit check dams in a typhoon prone environment. We further acknowledge that in depth analysis should be carried out in future studies to discuss in depth the efficiencies of slit check dams.

\section{References}

1 Ramos-Diez, I.; Navarro-Hevia, J.; San Martín Fernández, R.; Díaz-Gutiérrez, V.; Mongil-Manso, J. "Analysis of Methods to Determine the Sediment Retained by Check Dams and to Estimate Erosion Rates in Badlands." Environ. Monit. Assess., 188, 405, (2016).

2 Piton, G.; Recking, A. "Effects of Check Dams on Bed-Load Transport and SteepSlope Stream Morphodynamics." Geomorphology.

3 Catella, M.; Paris, E.; Solari, L. "Case Study: Efficiency of Slit-Check Dams in the Mountain Region of Versilia Basin." J Hydraul Eng-Asce, 131, 145-152, (2005). Chen, S.-C.; An, S.P. "Fine Sediment Trapping Effect by Porous Check Dams." J. Chinese Soil Water Conserv., 38, 55-63, (2006).

$5 \quad$ Chen, S.-C.; Kokuryo, H.; An, S.-P.; Lu, S.-J.; Huang, H.-K. "Sediment Trapping Efficiency of Modular Steel Check Dam in Laboratory Experiment and Field Observation." In INTERPRAEVENT, Nara, Japan, 2014.

6 Zou, Y.H.; Chen, X.Q. "Effectiveness and Efficiency of Slot-Check Dam System on Debris Flow Control." Nat. Hazards Earth Syst. Sci. Discuss., 2015, 5777-5804, (2015).

7 Tfwala, S.; Wang, Y.-M. "Estimating Sediment Discharge Using Sediment Rating Curves and Artificial Neural Networks in the Shiwen River, Taiwan." Water, 8, 53, (2016).

8 iRIC. "User Manual: Changing River Science." Hokkaido River Centre: Hokkaido, Japan, 2014.

9 Wu, W.; Wang, P.; Chiba, N. "Comparison of Five Depth-Averaged 2-D Turbulence Models for River Flows." Archives of Hydro-Engineering and Environmental Mechanics, 51, 183-200, (2004).

10 Lin, C.-P.; Chen, C.-N.; Wang, Y.-M.; Tsai, C.-H.; Tsai, C.-T. "Spatial Distribution of Soil Erosion and Suspended Sediment Transport Rate for Chou-Shui River Basin." J Earth Syst Sci, 123, 1517-1539, (2014).

11 Chen, C.N.; Tsai, C.H.; Tsai, C.T. "Simulation of Runoff and Suspended Sediment Transport Rate in a Basin with Multiple Watersheds." Water Resour. Manage., 25, 793-816, (2011).

12 Wu, C.H.; Chen, C.N.; Tsai, C.H.; Tsai, C.T. "Estimating Sediment Deposition Volume in a Reservoir Using the Physiographic Soil Erosion-Deposition Model." Int J Sediment Res, 27, 362-377, (2012).

13 Chen, J.Y.; Hong, Y.M. "Characterisitics of Check Dam Scour Hole by Free overFall Flow." J. Chin. Inst. Eng., 24, 673-680, (2001).

14 Garcia, C.C.; Lenzi, M.A. "Check Dams, Morphological Adjustments and Erosion Control in Torrential Streams." Nova Science Publishers, Incorporated, (2013).

15 Conesa-Garcia, C.; Garcia-Lorenzo, R. "Local Scour Estimation at Check Dams in Torrential Streams in South East Spain." Geogr Ann A, 91a, 159-177, (2009).

16 Liu, C.M. In The Effectiveness of Check Dams in Controlling Upstream Channel Stability in Northeastern Taiwan, Erosion, Debris Mows and Environment in Mountain Regions, Chengdu, China, July, 1992; IAHS: Chengdu, China. 